\title{
Avaliação da Expressão Tecidual do Gene de Reparo MLH1 e dos Níveis de Dano Oxidativo ao DNA em Doentes com Câncer Colorretal
}

\author{
Evaluation of Expression of Mismatch Repair Gene MLH1 and Levels of Oxidative \\ DNA Damage in Normal and Neoplastic Tissues of Patients with Colorectal Cancer
}

\author{
CARLOS AUGUSTO REALMARTINEZ ${ }^{1}$, ADRIANATEIXEIRACORDEIRO ${ }^{2}$, DENISE GONÇALVES PRIOLLI'; DANIEL \\ DUARTE DACONCEIÇÃO MIRANDA ${ }^{2}$, WALDEMAR BARTCHEWSKY JÚNIOR ${ }^{3}$, NELSON FONTANAMARGARIDO ${ }^{4}$, \\ MARCELOLIMA RIBEIRO 5
}

\begin{abstract}
${ }^{1}$ Professor Adjunto do Programa de Pós-Graduação em Ciências da Saúde da Universidade São Francisco. Chefe do Serviço de Cirurgia Geral do Hospital Universitário São Francisco, Bragança Paulista, (SP); ${ }^{2}$ Acadêmicos do Curso de Medicina da Universidade São Francisco, Bragança Paulista, (SP). Bolsistas e Iniciação Científica (FAPESP); ${ }^{3}$ PósGraduando em Ciências da Saúde da Universidade Federal de São Paulo, (SP); ${ }^{4}$ Professor Livre Docente do Departamento de Cirurgia da Faculdade de Medicina da Universidade de São Paulo, (SP); ${ }^{5}$ Professor Assistente do Programa de Pós-Graduação em Ciências da Saúde da Universidade São Francisco, Bragança Paulista, (SP).
\end{abstract}

\begin{abstract}
MARTINEZ CAR; CORDEIRO AT; PRIOLLI DG; MIRANDA DDC; BARTCHEWSKY JÚNIOR W; MARGARIDO NF; RIBEIRO ML. Avaliação da Expressão Tecidual do Gene de Reparo MLH1 e dos Níveis de Dano Oxidativo ao DNA em Doentes com Câncer Colorretal. Rev bras Coloproct, 2009;29(3): 303-313.

RESUMO: O dano oxidativo ao DNA provocado por radicais livres de oxigênio representa um dos principais mecanismos responsáveis pelas etapas iniciais da carcinogênese colorretal. $O$ estresse oxidativo ocasiona erros de pareamento de bases possibilitando o aparecimento de mutações em genes controladores do ciclo celular. As células possuem um sistema de defesa representado pelos genes de reparo do DNA que corrigindo os erros de pareamento impedem o desenvolvimento de mutações. Poucos estudos avaliaram a relação entre dano oxidativo ao DNA e a expressão tecidual do gene de reparo MLH1. Objetivo: O objetivo do presente estudo foi avaliar os níveis de estresse oxidativo ao DNA e a expressão tecidual do gene de reparo MLH1 nas células da mucosa cólica normal e neoplásica de doentes com câncer colorretal. Material e Método: Foram estudados 44 doentes com diagnóstico de adenocarcinoma colorretal. Foram excluídos os doentes com câncer colorretal hereditário, portadores de câncer relacionado às doenças inflamatórias intestinais e os submetidos à radioquimioterapia neoadjuvante. Para a avaliação dos níveis de dano oxidativo ao DNA utilizou-se a técnica da eletroforese alcalina em gel de célula isolada (ensaio do cometa) avaliando 100 células obtidas dos tecidos normal e neoplásico. Para a avaliação da expressão do gene MLH1 utilizou-se a técnica de reação de polimerase em cadeia em tempo real (RTPCR) com primer especificamente desenhados para amplificação do gene. A comparação dos resultados encontrados para os níveis de estresse oxidativo ao DNA, e expressão do gene MLH1 nos tecidos normais e neoplásicos foi feito pelo teste t de Student, adotandose nível de significância de $5 \%$ (p<0,05). Resultados: Os níveis de dano oxidativo ao DNA no tecido neoplásico foram significativamente mais elevados quando comparados ao tecido normal ( $p=0,0001)$. A expressão tecidual do gene MLH1 no tecido neoplásico foi significativamente menor quando comparado ao tecido normal $(p=0,02)$. Conclusão: $O$ gene de reparo MLH1 encontra-se menos expresso no tecido neoplásico e inversamente relacionado aos níveis de dano oxidativo ao DNA.
\end{abstract}

Descritores: Câncer Colorretal; Dano do DNA; Reparo do DNA; Estresse oxidativo; Ensaio em Cometa; Reação em Cadeia da Polimerase.

\section{INTRODUÇÃO}

O câncer colorretal (CCR) é a terceira neoplasia maligna mais frequente que acomete o ho- mem, representando uma das principais causas de morte em todo mundo. ${ }^{1,2}$ Não obstante os recentes avanços obtidos no diagnóstico precoce e tratamento, os índices de mortalidade nas últimas décadas pouco

\footnotetext{
Trabalho realizado no Programa de Pós-Graduação em Ciências da Saúde da Universidade São Francisco, Bragança Paulista, São Paulo. Conflito de interesses: nenhum

Fonte de Financiamento: Fundação de Amparo a Pesquisa de Estado de São Paulo (FAPESP). Número do Projeto: $n^{\circ}$ 08-51499-7.

$\overline{\text { Recebido em } 07 / 08 / 2009}$

Aceito para publicação em 04/09/2009
} 
Avaliação da Expressão Tecidual do Gene de Reparo MLH1 e dos Níveis de Dano Oxidativo ao DNA em Doentes com Câncer Colorretal Carlos Augusto Real Martinez e Cols. se alteraram ${ }^{1}$. No Brasil, a evolução do CCR tem apresentado comportamento semelhante sendo, atualmente, a quarta causa mais comum de morte relacionada ao câncer e, a exemplo do que acontece em outros países, sua incidência vem aumentando em comparação a outros tipos de tumores do aparelho digestivo. ${ }^{2}$ Estimativas mostram que no Brasil em 2008, ocorreram 27.000 casos novos de CCR, correspondendo a um risco estimado de 13-15casos-novos/100.000 habitantes. ${ }^{2} \mathrm{O}$ aumento da expectativa de vida, os fenômenos da globalização e, principalmente, a mudança de hábitos dietéticos fizeram com que o CCR ganhasse importância crescente no perfil da mortalidade por câncer em todo o mundo. ${ }^{1}$

Desde a publicação do trabalho pioneiro de Fearon e Vogelstein em $1990^{3}$, encontra-se bem estabelecido que o surgimento do CCR, a partir da mucosa cólica normal, é mediado por uma sequência de mutações em genes controladores do ciclo celular (proliferação, diferenciação, e apoptose) ou em genes responsáveis pelo reparo do DNA. A partir de então os grandes avanços no campo da biologia molecular vem permitindo a melhor compreensão dos mecanismos genéticos e moleculares envolvidos na carcinogênese colorretal. $^{4}$

O desenvolvimento do CCR é essencialmente um processo evolutivo somático clonal, envolvendo uma série de mutações ou mudanças na expressão de vários genes. Essas alterações conferem vantagens adicionais para o crescimento tumoral, em relação ao tecido normal. ${ }^{4}$ Contudo, os mecanismos iniciais responsáveis pela transformação da célula normal em célula neoplásica, ainda não se encontram totalmente esclarecidos. ${ }^{4}$ Estudos demonstraram que o dano ao DNA provocado pelos radicais livres de oxigênio (RLO) e a hipermetilação, incorporação de radicais metil $\left(\mathrm{CH}_{3}\right)$ na região promotora dos genes, representam dois dos principais mecanismos relacionados às etapas iniciais do desenvolvimento do CCR. ${ }^{5,6,7,8,9,10,11,12,13,14,15}$

Os RLO são constantemente formados durante o metabolismo energético normal de todas as células vivas. ${ }^{14}$ Entretanto, quando sua produção é excessiva, tornam-se nocivos às células danificando proteínas, membranas, organelas e bases nitrogenadas do DNA. ${ }^{16}$ Para se defender as células possuem sistemas de defesa antioxidantes, enzimáticos e não-enzimáticos, que atuam contra a toxicidade dos RLO sendo responsáveis pela manutenção da homeostase entre produção e neutralização. ${ }^{14,15,16,17}$ Em certas condições, quer pela diminuição dos sistemas antioxidantes do organismo, quer pelo aumento exagerado na produção de RLO, ocorre desequilíbrio, determinando o aparecimento de fenômeno conhecido como estresse oxidativo. ${ }^{16,17,18,19}$ Da mesma forma, a produção excessiva de radicais $\mathrm{CH}_{3}$ podem ocasionar hipermetilação da bases nitrogenadas que compõe as regiões promotoras dos genes determinando o bloqueio de sua transcrição.

Estudos demonstraram que o estresse oxidativo provoca quebras simples e duplas nas fitas que compõem as moléculas do DNA e induz a erros de pareamento das bases nitrogenadas possibilitando, consequentemente, aparecimento de mutações genéticas. 19,20,21,22 Quando a mutação ocorre em genes responsáveis pelo controle do binômio proliferação/morte celular poderá haver formação de um clone de células com autonomia proliferativa ou resistência a apoptose, características inerentes a célula neoplásica. ${ }^{23}$ Para que isso não ocorra, as células possuem mecanismos de defesa contra esses erros de pareamento representados pelos sistemas de reparo do DNA (mismatch repair- MMR). ${ }^{6,7,8,9,23}$ Os genes que compõe o sistema de reparo traduzem proteínas cuja função primordial é corrigir os erros de pareamento de bases impedindo a transmissão destas mutações a futuras gerações celulares. ${ }^{23}$ Dentre os principais genes de reparo destacam-se o MLH1, MSH2, PMS1, PMS2, MSH6 que apresentam importância na correção de mutações relacionadas ao estresse oxidativo e ao MGMT com importância na correção da incorporação de radicais $\mathrm{CH}_{3}$ em bases do DNA. 6,7,8,9,24,25,26

Recentes estudos vêm demonstrando que as células oriundas de tecidos neoplásicos obtidos de doentes com CCR apresentam maiores níveis de dano oxidativo ao DNA. ${ }^{22,27}$ Todavia, também demonstraram que no tecido normal desses mesmos doentes, apesar de existirem níveis consideráveis de dano oxidativo ao DNA as células não apresentam transformação neoplásica. ${ }^{20,22,27}$. É provável que a neoplasia não se desenvolva pela ação das proteínas de reparo que corrigem os danos ao DNA, provocados pelos RLO e pela hipermetilação. É possível que no tecido neoplásico, o sistema de reparo não consiga corrigir, com a mesma eficiência, os erros de pareamento de bases permitindo o surgimento de células com mutações genéticas. Essa possibilidade torna atraente o estudo das relações existentes entre estresse oxidativo e capacidade de reparo do DNA, comparando tecidos normais e neoplásicos. 
Avaliação da Expressão Tecidual do Gene de Reparo MLH1 e dos Níveis de Dano Oxidativo ao DNA em Doentes com Câncer Colorretal Carlos Augusto Real Martinez e Cols.
O objetivo do presente estudo foi avaliar a expressão do gene MLH1 e os níveis de estresse oxidativo ao DNA nuclear comparando células normais e neoplásicas da mucosa cólica de doentes com CCR.

\section{MATERIAL E MÉTODO}

O presente estudo recebeu aprovação do Comitê de Ética em Pesquisa da Universidade São Francisco. Todos os pacientes que forneceram material biológico para a pesquisa assinaram Termo de Consentimento Livre e Esclarecido após serem informados de todas as etapas experimentais.

\section{Casuística}

Foram elegíveis para o presente estudo 44 enfermos (22 mulheres), com média de idade de 62,4 anos, portadores de adenocarcinoma colorretal, submetidos a tratamento cirúrgico com intenção curativa, por uma mesma equipe cirúrgica entre janeiro de 2007 e dezembro de 2008. Foram excluídos os doentes com CCR hereditário (polipose adenomatosa familiar e câncer colorretal hereditário não polipóide), portadores de CCR associado à doença inflamatória intestinal, doentes operados em caráter de urgência e, aqueles submetidos a tratamento radioterápico ou quimioterápico neoadjuvante.

\section{Coleta do material}

Imediatamente após a remoção do espécime cirúrgico, foram retirados seis fragmentos da mucosa cólica normal distante no mínimo $10 \mathrm{~cm}$ da margem superior da neoplasia. Da mesma forma, foram colhidos seis fragmentos da mucosa neoplásica obtidos da periferia do tumor. Os fragmentos foram identificados e acondicionados, individualmente, em recipientes apropriados, e imediatamente, enviados ao Laboratório de Biologia Molecular da Universidade São Francisco, onde foram resfriados a $-80^{\circ} \mathrm{C}$, até o momento da realização das análises moleculares. Três fragmentos de cada tecido (normal e neoplásico) foram destinados ao estudo da expressão do gene MLH1 pela reação em cadeia de polimerase em tempo real (RT-PCR). Os seis fragmentos restantes provenientes dos tecidos normais e neoplásicos foram acondicionados em recipiente com solução de congelamento e destinados a mensuração dos níveis de estresse oxidativo ao DNA pela técnica da eletroforese alcalina em gel de célula isolada (ensaio do cometa). Os ensaios laboratoriais foram reali- zados em um único momento. Todos os doentes selecionados foram diagnosticados como portadores de adenocarcinoma pela técnica da hematoxilina-eosina por patologista experiente em neoplasias colorretais, que desconhecia os objetivos do presente estudo

\section{Eletroforese alcalina em gel de célula iso- lada (ensaio do cometa)}

Para a realização do ensaio do cometa foram utilizados os três fragmentos obtidos do tecido neoplásico e três fragmentos de tecido normal. A análise dos danos oxidativos ao DNA das células da mucosa cólica foi feita de acordo com método anteriormente proposto. ${ }^{28}$ Resumidamente, as amostras foram incubadas em $3 \mathrm{ml}$ de uma solução de Hank's (HBSS, Invitrogen, Carlsbad, CA, USA) contendo $5,5 \mathrm{mg}$ de proteinase K (Sigma Chemical CO, St. Louis, MO) e 3 mg de colagenase III (Invitrogen $®$ ) por 45 minutos a $37^{\circ} \mathrm{C}$ para a liberação das células. A seguir, foram resuspendidas em $10 \mathrm{ml}$ de HBSS e centrifugadas para o isolamento das células. Realizamos o ensaio do cometa apenas nas amostras que apresentassem viabilidade celular maior que $75 \%$. Avaliamos a viabilidade celular usando o método do diacetato de fluoresceína (FDA) / brometo de etídio (EtBr- Sigma-Aldrich, St Louis,MO,USA). Para o estudo da viabilidade, a solução de coloração celular foi preparada imediatamente antes da sua utilização e continha $30 \mathrm{ml}$ de FDA em acetona $(5 \mathrm{mg} / \mathrm{ml}), 200 \mathrm{ml}$ de EtBr em tampão fosfato (PBS; $200 \mathrm{mg} / \mathrm{ml}$ ), e 4,8 $\mathrm{ml}$ de PBS (Invitrogen, Carlsbad, CA, USA). A suspensão contendo células isoladas foi então misturada com $25 \mathrm{ml}$ da solução corante, colocada sobre lâmina e recoberta com lamínula. As lâminas foram lidas em microscópio de imunofluorescência. Ao núcleo das células viáveis coravam-se em verde, enquanto das células inviáveis em vermelho. Após análise das lâminas, selecionamos amostras dos tecidos que apresentassem mais de $75 \%$ das células viáveis.

A versão alcalina do ensaio do cometa foi realizada de acordo com Ladeira et al., 2004. ${ }^{29}$ De forma resumida, $15 \mu \mathrm{l}$ da suspensão celular previamente obtida foram misturadas a agarose "low melting point" $0,5 \%$ (Promega), postos sobre uma lâmina e cobertos com uma lamínula. Em seguida foram imersas em uma solução de lise gelada (2,5 M NaCl, $100 \mathrm{mM}$ EDTA, $10 \mathrm{mM}$ Tris, $1 \%$ SDS, pH 10 com $1 \%$ Triton X-100 e $10 \%$ DMSO) permanecendo a $4^{\circ} \mathrm{C}$ por 12 horas. Subsequentemente, foram expostas a um tampão al- 
Avaliação da Expressão Tecidual do Gene de Reparo MLH1 e dos Níveis de Dano Oxidativo ao DNA em Doentes com Câncer Colorretal Carlos Augusto Real Martinez e Cols. calino (1 mM EDTA e $300 \mathrm{mM} \mathrm{NaOH}, \mathrm{pH} \sim 13,4$ ) por $40 \mathrm{~min}$ a $4^{\circ} \mathrm{C}$. A eletroforese foi realizada neste tampão a $4^{\circ} \mathrm{C}$ por $30 \mathrm{~min}$ a $25 \mathrm{~V}$ e $300 \mathrm{~mA}$. Após a realização da eletroforese, as lâminas foram neutralizadas $(0,4$ M Tris, pH 7,5), coradas com SYBR Safe (Invitrogen, Carlsbad, CA, USA) e analisadas com um microscópio de fluorescência. Duzentas células foram aleatoriamente selecionadas (100 de cada amostra tecidual) e analisadas individualmente utilizando-se o software Komet 5.5 (Kinetic Imaging Ltd. - USA).

Com o auxílio do software obteve-se o valor da extensão da cauda do cometa (Tail Moment) sendo seus valores médios determinados. Segundo o manual do fabricante, o Tail Moment é definido como o produto do DNA da cauda e a distância média da migração da cauda. O tamanho da cauda reflete a extensão das rupturas das hélices de DNA (dano oxidativo), e pode ser quantificado por métodos de intensificação de imagem (Figura 1). Adotou-se como valor final para os níveis de dano oxidativo ao DNA nos tecidos normal e neoplásico a média dos valores encontrados nas três amostras analisadas de cada tecido.

\section{MLH1}

Expressão tecidual do gene de reparo

Para a avaliação da expressão do gene MLH1 a extração do RNA foi realizada a partir de três fragmentos da mucosa cólica normal e três da neoplásica, obtidos na periferia do tumor e removidos da margem proximal de ressecção nos mesmos doentes onde o ensaio do cometa foi concretizado. Para a estabilização e proteção do RNA, após a ressecção cirúrgica todas as amostras destinadas a este fim foram acondicionadas em frascos contendo RNA-later (QIAGEN, Valencia, CA, USA) e refrigeradas imediatamente à $80^{\circ} \mathrm{C}$ até o momento da extração do RNA. A extração do RNA foi feito em uma única bateria. Realizamos a extração do RNA com o emprego do RN-easy ${ }^{\circledR}$ tissue kit (QIAGEN) seguindo o protocolo do fabricante. Após a extração, aproximadamente $100 \mathrm{mg}$ de RNA foram utilizados para a síntese do cDNA usando o "high capacity cDNA archive kit" (Applied Biosystems, Foster City, CA, USA).

A análise da expressão do gene MLH1 e do gene constitutivo $\beta$-Actina foram feitas por RT-PCR. A reação de PCR em tempo real foi realizada no equipamento iCycler IQ ${ }^{\mathrm{TM}}$ (Bio-Rad, USA). Os experimentos foram feitos em triplicata, e as amostras foram normalizadas usando-se um dos controles constitutivos. Os primers e sondas utilizadas neste estudo foram desenhados usando o serviço TaqMan ${ }^{\circledR}$ de ensaio de expressão gênica (Applied Biosystems). O quadro 1 mostra os primes utilizados para a amplificação do gene MLH1 e do gene constitutivo $\beta$-actina.

A reação de PCR em tempo real foi realizada no equipamento iCycler IQ (Bio-Rad, USA). Os experimentos foram feitos em triplicata, e as amostras foram normalizadas usando-se um dos controles constitutivos. A expressão relativa foi calculada de acordo com fórmula $2^{(R t-E t) / 2(R n-E n)}$ previamente descrita ${ }^{30}$. O valor final adotado para a expressão do gene MLH1 foi o valor médio encontrado nos três fragmentos analisados em cada doente (três do tecido normal e três do neoplásico).

\section{Análise estatística}

Os resultados obtidos para os níveis de dano oxidativo ao DNA (Tail moment), expressão tecidual

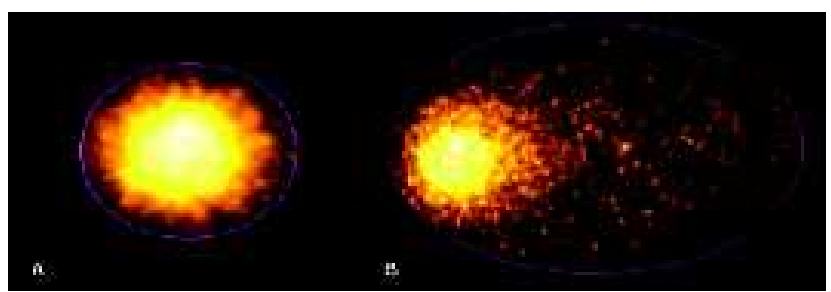

Figura 1 - Avaliação dos níveis de estresse oxidativo ("Tail Moment"), por meio da eletroforese em gel de célula única (ensaio do cometa). A - Célula normal; B - Célula com dano oxidativo intenso.

Quadro 1 - Primers que utilizados para amplificação dos genes MLH1 e $\beta$-actina.

\begin{tabular}{lll}
\hline Gene & Primer & Sequência $\left(\mathbf{5}^{\prime} \rightarrow \mathbf{3}^{\prime}\right)$ \\
\hline MLH1 & hMLH1-sense & CGGTTACTACCCAATGCCTCAAC[FAM]G \\
& hMLH1-antisense & TTCTCGACTAACAGCATTTCCAA \\
$\beta$-actin & $\beta$-actin-sense & CGGCTAATACACACTCCAAGGC[FAM]G \\
& $\beta$-actin-antisense & ACACTGGCTCGTGGACAAGG \\
\hline
\end{tabular}


Rev bras Coloproct Julho/Setembro, 2009
Avaliação da Expressão Tecidual do Gene de Reparo MLH1 e dos Níveis de Dano Oxidativo ao DNA em Doentes com Câncer Colorretal Carlos Augusto Real Martinez e Cols. do gene MLH1 foi representado segundo o valor médio com o respectivo erro padrão considerando os tecidos normal e neoplásico. Empregou-se o teste t de Student pareado na comparação entre os valores adotando-se intervalo de confiança de $95 \%$. Em todos os testes utilizados estabeleceu-se nível de significância de $5 \%(\mathrm{p}<0,05)$. Todos os dados obtidos foram analisados usando o programa estatístico SPSS 13.0 (SPSS Inc., Chicago, USA).

\section{RESULTADOS}

\section{Níveis de dano oxidativo ao DNA}

Os resultados obtidos pelo ensaio do cometa mostraram que, em média, os níveis de dano oxidativo ao DNA nuclear no tecido normal foram de 1,0490,06 $T M$, enquanto no tecido neoplásico de 2,552 $\pm 0,14 T M$. A tabela 1 mostra os valores médios, com o respectivo erro padrão, dos níveis de estresse oxidativo ao DNA (Tail Moment) nos 44 casos estudados, comparando os tecidos normais e neoplásicos. Verificou-se que os níveis de dano oxidativo a DNA foram significativamente mais elevados nas células da mucosa cólica do tecido neoplásico quando comparado com o das célu- las do epitélio normal ( $\mathrm{p}<0,00001$; IC-95\%: -1,7502 a $1,2544)$. As células da mucosa cólica obtidas dos tecidos normais já apresentavam algum grau de dano oxidativo ao DNA.

\section{Níveis de expressão do gene MLH1}

Os resultados obtidos com a amplificação do gene MLH1 mostraram que, em média, a expressão do gene no tecido normal foi de $0,5618 \pm 0,08 \mathrm{UA}$, enquanto no tecido neoplásico de $0,3532 \pm 0,02$ UA. A tabela 2 mostra a comparação entre os valores médios, com respectivo erro padrão e intervalo de confiança dos valores encontrados para a expressão do gene MLH1 nos tecidos normal e neoplásico. Verificou-se que no tecido normal os níveis de expressão do gene MLH1 foram significativamente maiores quando comparados ao tecido neoplásico ( $\mathrm{p}=0,02$; IC- 95\%: 0,0292 a 0,3873).

\section{DISCUSSÃO}

Defini-se como radical livre qualquer átomo ou molécula que contenha um número ímpar de elétrons na sua última camada eletrônica. ${ }^{14,17}$ A denominação RLO é adotada porque a maioria dos radicais livres é

Tabela 1 - Níveis de dano oxidativo ao DNA nuclear comparando tecidos normais e neoplásicos, na casuística total estudada.

\begin{tabular}{lccccc}
\hline \multicolumn{5}{c}{ Níveis de dano oxidativo ao DNA } \\
& \multicolumn{2}{c}{ (TM) } & & & \\
\cline { 2 - 3 } & Tecido Normal & Tecido Neoplásico & & \\
\hline $\mathbf{n}$ & Média \pm E.P. & Média \pm E.P. & I.C. 95\% & p \\
\hline 44 & $1,049 \pm 0,06$ & $2,552 \pm 0,14$ & $-1,7502 \mathrm{a}-1,2544$ & $0,00001 *$ \\
\hline
\end{tabular}

$T M=$ Tail moment $; n=$ número de doentes; E.P. = Erro padrão; I.C.95\% = intervalo de confiança $(95 \%) ; *=$ significativo; Teste $t$ Student pareado.

Tabela 2 - Comparação da expressão do gene MLH1 nas células normais e neoplásicas da mucosa cólica de doentes com câncer colorretal.

\begin{tabular}{lccccc}
\hline \multicolumn{5}{c}{ Gene MLH1 } \\
& \multicolumn{2}{c}{$($ UA) } & & & \\
\cline { 2 - 4 } & Tecido Normal & Tecido Neoplásico & & \\
\hline $\mathbf{n}$ & Média \pm E.P. & Média \pm E.P. & I.C. 95\% & p \\
\hline 44 & $0,5618 \pm 0,08$ & $0,3532 \pm 0,02$ & 0,0292 a 0,3873 & $0,02 *$ \\
\hline
\end{tabular}

U.A. = Unidades arbitrárias; $n=$ número de doentes; E.P. = Erro padrão; I.C. $95 \%=$ intervalo de confiança $(95 \%) ; *=$ significativo; Teste t Student pareado. 
Avaliação da Expressão Tecidual do Gene de Reparo MLH1 e dos Níveis de Dano Oxidativo ao DNA em Doentes com Câncer Colorretal Carlos Augusto Real Martinez e Cols. formada a partir do metabolismo celular do oxigênio. Os RLO são produzidos, constantemente, durante o metabolismo energético normal das células vivas. Outras condições, como a atividade bacteriana sobre substratos alimentares no interior da luz do cólon e a presença de inflamação da mucosa cólica também podem aumentar a formação de RLO. ${ }^{14,31}$

Durante o metabolismo energético celular dentro da cadeia respiratória mitocondrial inicialmente ocorre à formação do RLO denominado superóxido. Como o superóxido é danoso as células, a enzima superóxido dismutase catalisa a reação entre duas moléculas do radical e dois átomos de hidrogênio, formando o peróxido de hidrogênio $\left(\mathrm{H}_{2} \mathrm{O}_{2}\right) \cdot{ }^{16}$ Apesar de não ser considerado um RLO verdadeiro, por não apresentar elétrons desemparelhados na órbita externa de sua molécula, o $\mathrm{H}_{2} \mathrm{O}_{2}$ pela sua rápida capacidade de difusão celular e peroxidação lipídica, também é capaz de danificar membranas e organelas celulares. Para que isso não ocorra $\mathrm{O}_{2} \mathrm{O}_{2}$ é rapidamente convertido em água e oxigênio pela ação dos principais sistemas antioxidantes intracelulares representados pelas enzimas catalase e glutationa peroxidase. Todavia, quando existe produção excessiva de $\mathrm{H}_{2} \mathrm{O}_{2}$ ou quando os sistemas enzimáticos antioxidantes tornam-se insuficientes para transformálo em água e oxigênio, $\mathrm{o}_{2} \mathrm{O}_{2}$ forma o radical hidroxila $\left(\mathrm{OH}^{-}\right)$por meio das reações de Feanton e Haber-Weiss catalizadas pelo íon $\mathrm{Fe}^{++}$disponível no lúmen intestinal.

$\mathrm{O}$ radical $\mathrm{OH}^{-}$é considerado o mais reativo e danoso de todos os RLO pela sua alta capacidade lesiva tecidual. ${ }^{14,16} \mathrm{~A} \quad \mathrm{OH}^{-}$é eletrofílica com atividade altamente reativa atacando, principalmente, substâncias com alta densidade de elétrons, tais como as bases nitrogenadas que formam a molécula do DNA. ${ }^{10,13,14,15,16}$ Dentre os mecanismos mais bem estudados de estresse oxidativo ao DNA, encontra-se a hidroxilação da base guanina ocasionada pelo radical $\mathrm{OH}^{-}$. Quando a base guanina é exposta a grandes concentrações do radical $\mathrm{OH}^{-}$ocorre à incorporação de uma $\mathrm{OH}^{-}$no carbono oito de sua molécula, formando a 8-hidroxiguanina (8-OHdG). ${ }^{20,22,27,28,29}$ Durante o processo de duplicação do DNA, a base guanina pareiase, normalmente, com a molécula de citosina (G-C). Contudo, quando existe a formação da 8-OHdG, por um fenômeno conhecido como transversão de bases, a molécula a 8-OHdG pareia-se, de forma errônea, com uma molécula de timina (G-C ${ }^{\circledR}$ G-T), levando ao aparecimento de uma mutação. ${ }^{22} \mathrm{Na}$ eventualidade de não haver identificação deste erro de pareamento pela proteína p53, ou correção da transversão de bases pelos sistemas de reparo do DNA, poderá haver transcrição de um RNA mensageiro alterado, com a consequente tradução de uma proteína defeituosa. ${ }^{22}$ Caso esta proteína mutante seja responsável por um dos mecanismos de controle do ciclo celular ou ao próprio sistema de reparo, a célula poderá ganhar autonomia proliferativa, imortalidade e incapacidade de reparo do DNA, características inerentes às células neoplásicas. ${ }^{22}$ Este desequilíbrio do ciclo celular, com favorecimento da proliferação em detrimento da apoptose, e deficiências nos mecanismos de reparo do DNA representa a base da explicação molecular para transformação neoplásica a partir do epitélio normal. ${ }^{22}$ Reforçam essas evidências estudos demonstrando níveis progressivamente maiores de estresse oxidativo ao DNA ao comparar-se tecidos normais, inflamados, adenomas com graus progressivos de displasia tecidual e carcinomas. ${ }^{10,13}$

Durante os últimos anos diferentes métodos bioquímicos e analíticos foram desenvolvidos com o objetivo de avaliar a presença do estresse oxidativo nos tecidos humanos. ${ }^{28,29}$ Entretanto, estas técnicas não permitem mensurar, de modo fidedigno, o dano oxidativo ao DNA nuclear de uma única célula. Habitualmente, a quantificação do dano oxidativo tecidual envolve técnicas de extração do DNA dos tecidos e análise por cromatografia a gás, cromatografia líquida de alta performance, quantificação sérica, tecidual ou urinária de $8-\mathrm{OHdG}$ ou métodos imunoistoquímicos. ${ }^{22}$ Geralmente estas técnicas são dispendiosas, não podem ou são difíceis de serem aplicadas em pequenas amostras de tecido. ${ }^{22}$ Por esta razão, encontram-se poucos estudos comparando os níveis de estresse oxidativo ao DNA de células nas diferentes etapas evolutivas do processo de carcinogênese colorretal. ${ }^{10,19,20,22}$ A possibilidade de mensurar os níveis de dano oxidativo ao DNA nuclear em uma única célula em diferentes estágios da carcinogênese poderia contribuir para melhor compreensão do papel representado pelos RLO em todas as etapas do desenvolvimento do CCR, bem como a avaliação do potencial terapêutico de substâncias antioxidantes na prevenção dos danos provocados por esses radicais.

Singh et al. ${ }^{32}$ em 1988 desenvolveram uma técnica simples, capaz de detectar os níveis de estresse oxidativo ao DNA nuclear de uma célula isolada. Esta técnica foi inicialmente chamada de eletroforese alcalina em gel de célula isolada, hoje mais conhecida como "ensaio do cometa". A partir de sua descrição a técnica vem sendo cada vez mais utilizada como método 
Avaliação da Expressão Tecidual do Gene de Reparo MLH1 e dos Níveis de Dano Oxidativo ao DNA em Doentes com Câncer Colorretal Carlos Augusto Real Martinez e Cols. fidedigno de avaliação dos níveis de dano oxidativo ao DNA nuclear de células dos mais diferentes tecidos. ${ }^{19,20,22,29} \mathrm{O}$ ensaio do cometa permite de maneira simples, precisa e com baixo custo a quantificação dos níveis de estresse oxidativo ao DNA em pequenas quantidades de tecido. ${ }^{22}$ A maior vantagem do método, é a possibilidade de quantificar os níveis de dano oxidativo ao DNA nuclear de uma única célula, permitindo a interpretação individualizada do estresse oxidativo a cada célula da mucosa cólica nos diferentes estágios da carcinogênese. ${ }^{22,29}$ A quantificação dos níveis de dano oxidativo do DNA por analise computacional, individualmente em cada célula e em uma grande população de células obtidas de um mesmo local, torna a interpretação dos níveis de estresse oxidativo mais objetiva, representando com mais fidelidade os efeitos dos RLO sobre DNA nuclear.

A quantificação dos níveis de estresse oxidativo é essencial para a melhor compreensão do mecanismo de ação dos RLO sobre o DNA, bem como seus efeitos moleculares. Estudos que avaliaram os níveis de estresse oxidativo ao DNA em doentes com câncer gástrico e CCR, pelo ensaio do cometa, encontraram níveis progressivamente maiores de dano ao DNA quando compararam amostras obtidas de tecidos inflamados e neoplásicos com as de tecidos normais. ${ }^{10,13,19,20,21,22,27,33}$ A relação entre estresse oxidativo, inflamação, pólipos adenomatosos e câncer torna-se evidente quando se demonstrou níveis elevados de dano oxidativo ao DNA em células da mucosa cólica de doentes com retocolite ulcerativa inespecífica de longa duração e que desenvolveram displasias de alto grau e CCR. ${ }^{10,16,33,34}$

Poucos estudos avaliaram os níveis de estresse oxidativo ao DNA, com o ensaio do cometa, comparando tecidos normais e neoplásicos em doentes com CCR..$^{22,28,35}$ Esses estudos mostraram níveis duas vezes mais elevados de 8-OHdG no tecido neoplásico comparado ao tecido normal. ${ }^{22}$ Constataram que em $71 \%$ dos doentes o gene p53, de fundamental importância na identificação de erros de pareamento de bases nitrogenadas, apresentava elevados índices de dano oxidativo, destacando a importância da relação entre estresse oxidativo e mutações neste gene. ${ }^{27}$ Mostraram ainda que o tipo de mutação mais frequentemente encontrada no gene p53 foram erros de pareamento de bases do tipo transversão $(\mathrm{G} 囚 \mathrm{~T})$, justamente o tipo de mutação mais relacionada ao estresse oxidativo. ${ }^{27}$ Dessa maneira é possível que a ação dos RLO sob o gene p53 ocasione erros de pareamento de bases com modificação da síntese da proteína homônima e, consequentemente, do mecanismo de controle da apoptose celular programada. ${ }^{27}$ Todavia, estudos também chamam a atenção para o fato de que apesar dos níveis de estresse oxidativo serem significativamente mais elevados no tecido neoplásico, nos tecidos normais, apesar de não ocorre qualquer modificação histológica, já se encontram níveis consideráveis de dano ao DNA. A manutenção de uma população de células normais mesmo submetidas a considerável estresse oxidativo sugere uma atividade preservada dos sistemas de reparo. ${ }^{22,35}$

Os resultados que encontramos no presente estudo estão de acordo com os descritos anteriormente quando observamos níveis de estresse oxidativo ao DNA significativamente mais elevados no tecido neoplásico quando comparados aos do tecido normal $\left(2,552 \pm 0,14\right.$ x $1,049 \pm 0,06$, respectivamente)..$^{22,27,28,35} \mathrm{Da}$ mesma forma, é importante ressaltar, que também encontramos no tecido normal algum grau de dano oxidativo do DNA reforçando a importância dos RLO nas etapas iniciais da agressão tecidual que precedem o aparecimento da célula neoplásica. É provável que nos tecidos normais, eventuais erros de pareamento provocados pelo estresse oxidativo tenham sido reconhecidos pela proteína p53 normal e corrigidos pelos sistemas de reparo. Reforça essa possibilidade o fato de não encontrarmos atipias celulares nesses tecidos.

Para elucidar o processo de carcinogênese colorretal, o melhor conhecimento dos mecanismos envolvidos no sistema de reparo do DNA é um assunto de interesse crescente. ${ }^{23}$ Nas células eucarióticas, os sistemas de reparo do DNA são responsáveis pela correção de erros de pareamento das bases nitrogenadas. ${ }^{6,7,8,9}$ É sabido que o acúmulo de mutações no DNA pode ser resultante de deficiências dos sistemas de reparo. Até o momento, vários genes foram descritos como sendo capazes de sintetizar proteínas com função de reparo do DNA e entre eles merecem destaque o MLH1, MSH2, PMS1, PMS2, MSH6 e MGMT. ${ }^{23,25}$

As proteínas sintetizadas pelos genes de reparo possuem a capacidade de remover um segmento de DNA contendo uma alteração na sequência de bases (A-T;C-G) e inserir um novo segmento contendo a sequência correta, o que é feito baseado na sequiência existente no "molde" da fita complementar do DNA. ${ }^{23}$ A falha no funcionamento destas proteínas, portanto, causa grande instabilidade no genoma, ou seja, os defeitos na sequência do pareamento de bases, não po- 
Avaliação da Expressão Tecidual do Gene de Reparo MLH1 e dos Níveis de Dano Oxidativo ao DNA em Doentes com Câncer Colorretal Carlos Augusto Real Martinez e Cols. derão ser reparados adequadamente. ${ }^{4,23}$ A ineficiência na correção dos erros de pareamento é melhor demonstrada nas regiões chamadas de microssatélites onde normalmente ocorre repetição constante na sequência de duas ou três bases. Quando existem modificações na disposição dessa sequência de bases em uma região específica de microsatélites (instabilidade de microssatélites) ao comparar-se tecidos normais e neoplásicos a neoplasia é considerada como decorrente a erros de replicação (RER+). Quando esses erros ocorrem nas regiões codificadoras dos genes favorecem o surgimento de mutações e, consequentemente, tradução de proteínas defeituosas. ${ }^{17}$ Estudos recentes demonstraram que o silenciamento do gene MLH1 encontra-se relacionado ao desenvolvimento do CCR associado a erros de replicação pesquisados pelo estudo da instabilidade de microssatélites. . $^{6,9,9,25,26,36}$

O gene de reparo MLH1, também conhecido como HNPCC2, FCC2 e hMLH1, localiza-se no cromossomo 3 na posição 3p23-p21 e apresenta 19 éxons codificadores. ${ }^{36} \mathrm{O}$ MLH1 é um dos mais importantes genes do sistema de reparo do DNA humano e mutações nesse gene encontram-se relacionadas a vários tipos de câncer. ${ }^{23,36} \mathrm{O}$ sistema é composto por dois complexos protéicos: as proteínas MutS que incluem MSH2, MSH3 e MSH6 e as proteínas MutL que englobam MLH1, PMS1, PMS2 e MLH3. ${ }^{37}$ Para o funcionamento do sistema de reparo é necessário que o complexo protéico MutL se ligue a MutS-a (MSH2 e MSH6) ou MutS-b (MSH2 e MSH3). ${ }^{38}$ Já se demonstrou que este é um dos principais sistemas envolvidos na correção dos erros de pareamento de base do DNA provocados pelo estresse oxidativo. ${ }^{36} \mathrm{~A}$ importância do gene MLH1 e da proteína de reparo por ele transcrita na carcinogênese colorretal é melhor avaliada quando se sabe que indivíduos que apresentam defeitos herdados no gene MLH1, desenvolvem precocemente o CCR hereditário não associado à polipose (HNPCC), bem como neoplasias associadas em diferentes órgãos (endométrio, tireóide, trato urogentital). ${ }^{4,23,39}$ As regiões localizadas entre os códons 578 e 756 do gene MLH1 apresentam maior possibilidade de mutações que também ocorrem por erros no pareamento de bases ocasionadas pelo mecanismo de transversão. ${ }^{39}$ Estudos mostraram que 95\% dos portadores de HNPCC apresentam mutações herdadas do gene MLH1, enquanto apenas $20 \%$ dos doentes portadores de CCR esporádico apresentam a mutação. ${ }^{4,23}$ Já se demonstrou que o gene de reparo MLH1 encontra-se menos expressos nos tecidos neoplásicos dos doentes com CCR esporádico por diversos mecanismos representados, principalmente pela hipermetilação da região promotora do gene ou perda da heterozigosidade. ${ }^{6,7,8,9,25,37}$

Os resultados do presente estudo parecem confirmar estes achados quando encontramos em doentes com CCR esporádico menor expressão tecidual do gene MLH1 no tecido neoplásico quando comparada ao do tecido normal $(0,3532 \pm 0,02 \times 0,5618 \pm 0,08$, respectivamente). Como não avaliamos a hipermetilação da região promotora do gene, bem como não realizamos seu sequenciamento não podemos assegurar que essa menor expressão tecidual se deva a uma dificuldade de leitura do gene hipermetilado ou a uma transversão no pareamento de uma de suas bases provocada pelo estresse oxidativo. Da mesma forma não realizamos a pesquisa imunoistoquímica tecidual da proteína MLH1 não sendo possível afirmar que a menor expressão gênica resulte em menor expressão tecidual da proteína mutante. Todavia, a ausência de células neoplásicas no tecido normal permite concluir que neste tecido a maior expressão do gene MLH1, apesar de existir algum grau de dano oxidativo ao DNA, corrige eventuais erros de pareamento provocados pelos RLO.

Estudos anteriores também demonstraram a importante relação existente entre deficiências no sistema de reparo e o desenvolvimento de CCR. ${ }^{5,6,7,8,9,11}$ Diferentes possibilidades podem explicar a menor expressão dos genes de reparo no tecido neoplásico em doentes com CCR esporádico. É possível que exista dano oxidativo ao DNA nuclear nas porções codificadoras dos genes de reparo e que o dano não corrigido determine menor expressão e consequentemente menor síntese da respectiva proteína. Reforçam essas suspeitas, estudo chamando a atenção para a possibilidade de que a perda da heterozigosidade dos genes de reparo possa ser um dos mecanismos responsáveis pela sua menor expressão no tecido neoplásico. ${ }^{40}$ É possível que esta perda de heterozigosidade também possa ser devida a ação dos RLO danificando a porção codificadora do alelo dominante. Entretanto, estudos mais recentes vêm demonstrando que a diminuição da expressão dos genes de reparo em portadores de CCR esporádico, provavelmente, encontra-se mais relacionada à hipermetilação da região promotora desses genes, fazendo com que eles não possam ser transcritos e consequentemente expressos nos tecidos neoplásicos..$^{5,6,7,8,9}$ 
Rev bras Coloproct Julho/Setembro, 2009
Avaliação da Expressão Tecidual do Gene de Reparo MLH1 e dos Níveis de Dano Oxidativo ao DNA em Doentes com Câncer Colorretal Carlos Augusto Real Martinez e Cols.
Vol. 29
Os resultados encontrados no presente estudo confirmam a validade da eletroforese em gel de célula única na quantificação dos níveis de estresse oxidativo ao DNA nuclear em doentes com CCR. A quantificação foi realizada a partir de pequenas amostras de tecido que poderiam ser obtidas, a partir de biópsias endoscópicas. A avaliação do estresse oxidativo em uma série de biópsias obtidas de um mesmo enfermo possibilita a comparação dos níveis de dano oxidativo em tecidos normais, com diferentes graus de displasia e no tecido neoplásico. Portanto, trata-se de técnica exequível que permite a determinação dos níveis de estresse oxidativo celular ao longo de todas as etapas do processo de desenvolvimento do CCR.

Os resultados encontrados confirmam achados anteriores mostrando que no tecido neoplásico existem maiores níveis de estresse oxidativo quando comparados aos tecidos normais e que no tecido normal, apesar de existir algum grau de dano de DNA, não ocorre transformação neoplásica. ${ }^{22,35}$ Essas evidências reforçam a importância da integridade dos sistemas de reparo do DNA nesses tecidos. A atividade do sistema de reparo proporcionado pelo gene MLH1 encontra-se significativamente reduzida no tecido neoplásico, sugerindo que estes tecidos possam estar sofrendo acúmulo de mutações devido a ineficiência desse sistema. É possível que a expressão preservada do gene MLH1 nos tecidos normais possa, mantendo a síntese da proteína específica, corrigir o DNA eventualmente alterado, impedindo a transformação neoplásica.
Estudos com maior número de doentes, correlacionando o estresse oxidativo a expressão tecidual de cada um dos genes envolvidos no sistema de reparo do DNA ainda são necessários para avaliar de forma mais precisa o papel desempenhado pelos RLO no desenvolvimento do CCR. Com o advento de técnicas de microarray, que possibilitam o estudo simultâneo da expressão de um grande número de genes, concomitantemente associadas a métodos de determinação dos níveis de oxidativo nuclear, será possível compreender melhor o papel de cada um desses genes na correção de mutações induzidas pelos RLO. A avaliação dos níveis de dano oxidativo ao DNA nuclear, e a atividade do sistema de reparo nas diferentes etapas da carcinogênese colorretal permitem avaliar a eficácia de substâncias com atividade antioxidante como medida preventiva contra o estresse oxidativo à mucosa cólica e conseqüentemente o desenvolvimento do CCR.

\section{CONCLUSÕES}

Os resultados do presente estudo permitem concluir que células do tecido neoplásico de doentes com CCR apresentam maiores níveis de estresse oxidativo ao DNA nuclear quando comparados as do tecido normal. Constataram que a expressão do gene de reparo MLH1 é maior no tecido normal quando comparado ao tecido neoplásico demonstrando a importância desse gene na preservação da integridade DNA.

\footnotetext{
ABSTRACT: The oxidative DNA damage caused by oxygen free radicals is one of the most important mechanisms responsible for the initial steps of colorectal carcinogenesis. The oxidative stress can cause errors in the pairing of nitrogenous bases that form the DNA, allowing mutations in controlling genes of the cell cycle. The cells have a defense system represented by the DNA mismatch repair genes that correct the errors of matching prevent the development of DNA mutations. Few studies have evaluated the relationship between oxidative DNA damage and the tissue expression of mismatch repair genes. Aim: The aim of the present study was evaluate the levels of oxidative DNA and the tissue expression of MLH1 mismatch repair gene in the cells of normal and neoplastic colonic mucosa of patients with colorectal cancer. Material and Methods: Were studied 44 patients with diagnosis of colorectal adenocarcinoma. Were excluded patients with hereditary colorectal cancer, with colorectal cancer associate with inflammatory bowel diseases and those undergoing neoadjuvant radioquimiotherapy. To evaluate the levels of oxidative DNA damage was used the single cell gel electrophoresis (comet assay) evaluating 100 cells obtained from normal and neoplastic tissues. For the evaluation of the tissue expression of MLH1 gene was employed the technique of polymerase chain reaction in real time (RT-PCR) with primer specifically designed for MLH1 gene. The comparison among the levels of DNA oxidative stress and expression of MLH1 mismatch repair gene in normal and neoplastic tissues was done by Student $t$ test adopting a significance level of $5 \%(p<0.05)$. Results: The levels of oxidative DNA damage in tumor tissue were significantly higher when compared to the level of the normal tissue $(p=0.0001)$. The tissue expression of MLH1 mismatch repair gene in tumor tissue was significantly lower when compared to normal tissue $(\mathrm{p}=\mathbf{0 . 0 2})$. Conclusion: The mismatch repair gene MLH1 are less expressed in tumor tissue and inversely related to levels of oxidative DNA damage.
}

Key words: Colorectal Cancer; DNA Damage; DNA Repair; Oxidative stress; Comet Assay; Polymerase Chain Reaction. 
Rev bras Coloproct Julho/Setembro, 2009
Avaliação da Expressão Tecidual do Gene de Reparo MLH1 e dos Níveis de Dano Oxidativo ao DNA em Doentes com Câncer Colorretal Carlos Augusto Real Martinez e Cols.
Vol. 29

\section{REFERÊNCIAS}

1. Boring CC, Squires TS, Tong T, Montgomery S. Cancer statistics 1994. CA Cancer J Clin.1994;44(1):7-26.

2. Instituto Nacional do Câncer. Estimativa 2008. Incidência de câncer no Brasil. Disponível em URL: http://www.inca.gov.br/ estimativa/2008/versaofinal.pdf Acesso em: 20/06/2009.

3. Fearon ER, Vogelstein B. A genetic model for colorectal tumorigenesis. Cell. 1990;61(5):759-67.

4. Liu Y, Bodner WF. Carcinogênese colorretal. In: Câncer do Cólon Reto e Ânus. Rossi BM, Nakagawa WT, Ferreira FO, Aguiar Júnior S. Lopes A, editores. São Paulo. Lemar-Teccmed, 2004. p.43-54.

5. Wheeler JM, Kim HC, Efstathiou JA, Ilyas M, Mortensen NJ, Bodmer WF. Hypermethylation of the promotor region of the E-cadherin gene (CDH1) in sporadic and ulcerative colitis associated colorectal cancer. Gut. 2003; 48(3):367-71.

6. Wheeler JM, Beck NE, Kim HC, Tomlinson IPM, Mortensen NJM, Bodmer WF. Mechanisms of inactivation of mismatch repair genes in human colorectal cancer cell lines: The predominant role of hMLH1. Proc Natl Acad Sci. 1999; 96(18):10296-301.

7. Wheeler JMD. Epigenetics, mismatch repair and colorectal cancer. Ann R Coll Surg Engl. 2005;87(1):15-20.

8. Herman J, Umar A, Polyak K, Graff JR, Ahuja N, Issa JPJ, et al.. Incidence and functional consequences of hMLH1 promoter hypermethylation in colorectal carcinoma. Proc Natl Acad Sci USA. 1998;95(12): 6870-5.

9. Kámory E, Kolacsek O, Ottó S, Csuka O. hMLH1 and hMSH2 somatic inactivation mechanisms in sporadic colorectal cancer patients. Pathol Oncol Res. 2003;9(4):236-41.

10. Seril DN, Liao J, Yang GY, Yang CS. Oxidative stress and ulcerative colitis-associated carcinogenesis: studies in humans and animals models. Carcinogenesis. 2003;24(3):353-62.

11. Schmutte C, Yang A S, Nguyen TT, Beart RW, Jones PA. Mechanisms for the involvement of DNA methylation in colon carcinogenesis. Cancer Res. 1996;56(10):2375-81.

12. Kondo $S$, Toyokuni $S$, Iwasa $Y$, Tanaka $T$, Ondera $H$, Hiai $H$, et al. Persistent oxidative stress in human colorectal carcinoma, but not in adenoma. Free Radic Biol Med. 1999;27(3-4):401-10.

13. Ferreira ALA, Matsubara LS. Radicais livres: conceitos, doenças relacionadas, sistema de defesa e estresse oxidativo. Rev Ass Med Bras. 1997;43(1):61-8.

14. Cadenas E, Davies KJ. Mitochondrial free radical generation, oxidative stress, and aging. Free Rad Biol Med. 2000;29(34):222-30.

15. Pravda J. Radical induction theory of ulcerative colitis. World J Gastroenterol. 2005;11(16);2371-84.

16. Halliwell B, Gutteridge JM. The antioxidants of human extracellular fluids. Arch Biochem Biophys.1990;280(1):1-8.

17. Gutteridge JM, Halliwell B. Free radicals and antioxidants in the year 2000. A historical look to the future. Ann N Y Acad Sci. 2000;899:136-47.
18. Duthie SJ, Collins AR The influence of cell growth, detoxifying enzymes and DNA repair on hydrogen peroxide-mediated DNA damage (measured using the comet assay) in human cells. Free Radical Biol Med. 1997; 22(4):717-24.

19. Pool-Zobel BL, Leucht U. Induction of DNA damage in human colon cells derived from biopsies by suggested risk factors of colon cancer. Mutat Res. 1997;375(2):105-16.

20. Ames BN, Shigenaga MK, Hagen TM. Oxidants, antioxidants, and the degenerative diseases of aging. Proc Natl Acad Sci USA. 1993;90(17): 7915-22.

21. Ribeiro ML, Priolli DG, Miranda DDC, Arçari DP, Pedrazzoli Júnior J. Martinez CAR. Analysis of oxidative DNA damage in patients with colorectal cancer. Clin Colorectal Cancer. 2008;7(4):267-72.

22. Pinho MSL, Rossi BM. As proteínas envolvidas na carcinogênese colorretal (IV). Rev bras Coloproct. 1998;18(4):278-82.

23. Blasi MF, Ventura I, Aquilina G, Degan P, Bertario L, Bassi C, et al. A human cell-based assay to evaluate the effects of alterations in the MLH1 mismatch repair gene. Cancer Res. 2006;66(18):9036-44.

24. Menigatti M, Truninger K, Gebbers JO, Marbet U, Marra G, Schär P. Normal colorectal mucosa exhibits sex- and segmentspecific susceptibility to DNA methylation at the hMLH1 and MGMT promoters. Oncogene. 2009;28(6):899-909.

25. Shen L, Kondo Y, Rosner GL, Xiao L, Hernandez NS, Houlihan JVPS, et al. MGMT promoter methylation and field defect in sporadic colorectal cancer. J Nat Cancer Inst. 2005;97(18):1330-8.

26. Oliva MR, Ripoll F, Muniz P, Iradi A, Trullenque R, Valls V, et al. Genetic alterations and oxidative metabolism in sporadic colorectal tumors from a Spanish community. Mol Carcinog. 1997;18(4):232-43.

27. Pool-Zobel BL, Abrahamse SL, Collins AR, Kark W, Gugler $\mathrm{R}$, Oberreuther D, et al. Analysis of DNA strand breakes, oxidized bases, and glutathione S-tranferase P1 in human colon cellsfrom biopsies. Cancer Epidemiol Biomarkers Prevention. 1999;8(7):609-14.

28. Ladeira MS, Rodrigues MA, Freire-Maia DV, Salvadori DM. Use of comet assay to access DNA damage in patients infected by Helicobacter pylori: comparisons between visual and image analysis. Mutat Res. 2005;586(1):76-86.

29. Buckhaults P, Rago C, St Croix B, Romans KE, Saha S, Zhang L, et al. Secreted and cell surface genes expressed in benign and malignant colorectal tumors. Cancer Res. 2001;61(19):6996-7001.

30. Pilcher J. Free radicals. Neonatal Netw. 2002;21(7):33-7.

31. Singh NP, McCoy MT, Tice RR, Schneider EL. A simple technique for quantitation of low levels of DNA damage in individual cells. Exp Cell Res. 1988;175(1):184-91.

32. D'Inca R, Cardin R, Benazzato L, Angriman I, Martines D, Sturniolo GC. Oxidative DNA damage in the mucosa of ulcerative colitis increases with disease duration and dysplasia. Inflamm Bowel Dis. 2004;10(1):23-7. 
33. Kawanishi S, Hiraku Y, Pinlaor S, Ma N. Oxidative and nitrative DNA damage in animals and patients with inflammatory diseases in relation to inflammation-related carcinogenesis. Biol Chem. 2006;387(4):365-72.

34. Ribeiro ML, Priolli DG, Miranda DDC, Paiva DA, Pedrazzoli Júnior J, Martinez CAR. Avaliação do dano oxidativo ao DNA de células normais e neoplásicas da mucosa cólica de doentes com câncer colorretal. Rev bras Coloproct. 2007;27(4):391402.

35. Han HJ, Maruyama M, Baba S, Park JG, Nakamura Y. Genomic structure of human mismatch repair gene, hMLH1, and its mutation analysis in patients with hereditary nonpolyposis colorectal cancer (HNPCC). Hum Molec Genet. 1995; 4: 237-42.

36. Kolodner RD, Marsischky GT. Eukaryotic DNA mismatch repair. Curr Opin Genet Dev. 1999;9(1):89-96.
37. Mazurek A, Berardini M, Fishel R. Activation of human MutS homologs by 8-oxo-guanine DNA damage. J Biol Chem. 2002;277(10):8260-6.

38. Papadopoulos N, Nicolaides NC, Wei YF, Ruben SM, Carter $\mathrm{KC}$, Rosen CA, et al. Mutation of a mutL homolog in hereditary colon cancer. Science. 1994; 263:1625-9.

39. Sanchez de Abajo A, de la Hoya M, van Puijenbroek M, Godino J, Díaz-Rubio E, Morreau H, et al. Dual role of LOH at MMR loci in hereditary non-polyposis colorectal cancer? Oncogene. 2006;25(14):2124-30.

\section{Endereço para correspondência:}

\section{CARLOS AUGUSTO REAL MARTINEZ}

Rua Rui Barbosa, 255 apto. 32

Vila Boa Vista - Santo André - São Paulo

CEP: 09190-370 - Tel: (11) 4438-9203

E-mail: caomartinez@uol.com.br 